\title{
Improvement of Laccase Production in Pluerotus pulmonarius-LAU 09 by Mutation
}

\author{
Adebayo Elijah. Adegoke,", Oloke Julius. Kola ${ }^{1}$, Achana Yadav², Bora Tarun. Chandral ${ }^{2}$ \\ ${ }^{1}$ Department of Pure and Applied Biology, Ladoke Akintola University of Technology, P.M.B. 4000, Ogbomoso, Nigeria \\ ${ }^{2}$ North East Institute of Science and Technology, CSIR, Jorhat, Assam, 785006, India
}

\begin{abstract}
The strain improvement of P. pulmonarius LAU 09 for laccase production was carried out by UV- light exposure at $210 \mathrm{~nm}$ (UV-sterilizer, Millipore xx63 70000) for 90minutes. The highest laccase activity of 2.5 Uml-1 was produced by LAU 90 (mutant) in comparison with obtained yield by wild type LAU 09 (1.75 Uml-1). The optimal physiological parameters for optimum laccase production by LAU 90 are $30 \mathrm{OC}$ of temperature, $\mathrm{pH}$ of 5.0 and incubation of 168hours. The mutant strain gave the highest total enzyme activity and enzyme specific activity of $71.7 \times 10-4 \mathrm{~mol} / \mathrm{min}$ and $89.63 \mathrm{X} 10-4 \mathrm{IU} / \mathrm{mg}$ of purified laccase enzyme respectively, with molecular weight of 97KDa. The activity of the purified enzyme was strongly inhibited by Sodium azide and EDTA at $1 \mathrm{ml} / 0.1 \mathrm{mM}$ and $0.5 \mathrm{ml} / 100 \mathrm{mM}$ respectively. The result obtained shown an improved performance of the mutant (LAU 90) strain of P. pulmonarius in laccase production over the wild (LAU 09) type.
\end{abstract}

Keywords Strain, Improvement, Mutation, Laccase, Enzyme

\section{Introduction}

Laccases are multinuclear copper-containing glycoproteins that belong to the family of enzymes known as oxidases, more specifically "blue" oxidases[25], and polyphenol oxidases[8]. Laccases are one of six enzyme classes capable of reducing dioxygen to water, five of which belong to the multicopper oxidase family (the only enzyme not in this class being cytochrome-c oxidase, a heme/copper containing enzyme). Laccase is a polyphenol oxidase, indicative of the fact that laccases can oxidize a phenolic substrate that in turn can initiate a polymerization reaction[8]. Laccases from various sources vary greatly with respect to their degree of glycosylation, molecular weight and kinetic properties[25].

Basidiomycetes fungi especially Pleurotus species are the most efficient lignin-degrading organisms that produce mainly laccases (EC 1.10.3.2), lignin peroxidase (EC 1.11. 10.14) and manganese peroxidase (EC1.11.1.13). These enzymes present a non-specific biocatalyst mechanism and have been used for bioremediation process due to their ability to degrade azo, heterocyclic, reactive and polymeric dyes[1, 6]. Prospection for fungi is the ability to secret high levels of lignin-degrading enzymes and novel enzyme variants, with desirable properties for biotechnological applications. On the other hand, alternative low cost substrates like agricultural residues for enzyme production using solid

* Corresponding author:

brogoke2003@yahoo.com. (Adebayo Elijah. Adegoke)

Published online at http://journal.sapub.org/microbiology

Copyright (C) 2012 Scientific \& Academic Publishing. All Rights Reserved state fermentation (SSF) offer economic and environmental advantages. The main technological applications of laccases are in the textile, dye or printing industries, in processes related to decolouration of dyes[4], in the pulp and paper industries for the delignification of woody fibres, particularly during the bleaching process[3,13]. In most of these applications, laccases are used together with a redox mediator. At the end of 2005 three industrial processes were using laccases: dye bleaching, lignin bleaching and bleaching of cork for bottled wine[19].

Laccases exhibit a broad natural substrate range, which is a major reason for the attractiveness of laccases to biotechnological applications[16]. Even more interesting however is the application of laccase activity to a broader substrate range through the secondary activity of the free (cation) radical formed by oxidation of its substrates. The substrates that result in this type of activity towards other compounds are termed mediators. The industrial applicability of laccase may therefore be extended by the use of a laccase-mediator system. In view of the importance of laccase mentioned above, the improve production of the enzyme is inevitable.

Ultra violent radiation (UV- light) has been reported as one of the best physical method of strains improvement for better yield performance[10]. This method has been employed in improving enzyme production in Aspergillus niger [10], Rhizopus oryzea[22], mycelia cell and sporophore production in P. florida and P. sajor-caju[20]. However, no report is available on the improvement of laccase production by $P$. pulmonarius using UV- light radiation exposure.

The present investigation was undertaken to improve the laccase production by $P$. pulmonarius - LAU 09 strain 
through exposure to UV-light radiation.

\section{Material and Methods}

\section{Mutation Induction}

The actively growing culture (7 days old) of P. pulmonarius LAU 09 on PDA plates $(90 \mathrm{~mm})$ were exposed to UV-light (210 nm, Millipore xx63 70000) for 90mins. The mutants were subcultured on the PDA with $5 \%$ of yeast extract agar (YEA), incubated at $25^{\circ} \mathrm{C}$ for 7 days.

\section{Enzyme Assays}

The strains, both LAU 09 (wild) and LAU 90 (mutant) were grown in PDB with $5 \%$ of yeast extract (YE). The experiments were carried out in $250 \mathrm{ml}$ Erlenmeyer flask with $50 \mathrm{ml}$ of substrate, inoculated with a plug $(6 \mathrm{~mm})$, incubated at $25^{\circ} \mathrm{C}$ for 5 days at $150 \mathrm{rpm}$. The culture were sieved (Whatman paper II), centrifuged and filtrate were used as crude enzymes. Laccase activity was determined via the oxidation of 2, 2-azino-bis (3-ethylbenzthiazoline)- 6sulfonate (ABTS) (Sigma, America). The reaction mixture containing $0.1 \mathrm{ml}$ of $0.3 \mathrm{mM}$ ABTS in $100 \mathrm{mM}$ of Sodium acetate $(\mathrm{pH} 3.5)$ and $0.1 \mathrm{ml}$ of crude enzyme solution was incubated at $40^{\circ} \mathrm{C}$ for $1 \mathrm{~min}$. The $\mathrm{ABTS}$ oxidation was monitored by the increased in absorbance at $420 \mathrm{~nm}(\epsilon=$ $36000 \mathrm{M}^{-1} \mathrm{~cm}^{-1}$ ). One unit was defined as $1 \mu \mathrm{mol}$ of ABTS oxidized per minute and activity was expressed in Uper ML per min[15].

\section{Effect of temperature on enzymes production}

The optima temperature for laccase enzymes for LAU 09 and LAU 90 strains were evaluated by incubating the enzymes at different temperature ranges $\left(25^{\circ} \mathrm{C}, 30^{\circ} \mathrm{C}, 35^{\circ} \mathrm{C}\right.$, $40^{\circ} \mathrm{C}, 45^{\circ} \mathrm{C}$ and $50^{\circ} \mathrm{C}$ ) with appropriate substrates and buffers as described above.

\section{Effect of $\mathbf{p H}$ on enzymes production}

The optima $\mathrm{pH}$ for laccase was determined by incubating the enzyme with their appropriate substrates at their optimum temperature using Mcllvaine's method[17].

\section{Effect of incubation period on enzymes production}

The optimum incubation period for laccase production was determined by incubating the enzyme with their appropriate substrate at their optimum temperature for 9days[17].

\section{Acetone precipitation}

The crude enzymes $(20 \% \mathrm{w} / \mathrm{v}), 10,000 \mathrm{~g}$ supernatant was subjected to $80 \%$ acetone precipitation at $-4^{\circ} \mathrm{C}$. The contents were then placed in ice for an hour and then centrifuged at $10,000 \mathrm{~g}$ for $30 \mathrm{~min}$ at $-4^{\circ} \mathrm{C}$. The pellet was re-dissolved in $0.1 \mathrm{M}$ glycine- $\mathrm{NaOH}, \mathrm{pH} 10.0$.

\section{Ion exchange column chromatography}

Aliquots $(3 \mathrm{~mL})$ of the acetone precipitated proteins were applied to a column of Sephadex A-50 ion exchange resin (30 X $0.8 \mathrm{~cm}$ ) equilibrated with $0.1 \mathrm{M}$ citrate buffer, $\mathrm{pH} 5$. The protein sample volume was adjusted to $10 \%$ of the column bed volume. The ion exchange

Chromatography of the proteins was carried out at room temperature $\left(35^{\circ} \mathrm{C}\right)$. Following sample application, the column was washed with the equilibrating buffer, until the absorbance of the wash at A280 was $<0.05$. The adsorbed proteins were then eluted using a linear gradient of $\mathrm{NaCl}$ $(0-1.0 \mathrm{M})$ in $0.1 \mathrm{M}$ glycine- $\mathrm{NaOH}$ buffer, $\mathrm{pH} 10.0$ at a flow rate of $0.9 \mathrm{~mL} / \mathrm{min}$. Fractions of $2 \mathrm{~mL}$ were collected manually. Protein content of each fraction was evaluated at A280 employing a UV-vis double beam spectrophotometer (Spectra scan UV 2700: Thermo Scientific). Laccase activity in the fractions was determined using the enzyme assay as described above.

\section{Sephadex G-100 gel permeation column chromato- graphy}

Sephadex G-100 was allowed to swell in $0.1 \mathrm{M}$ glycine- $\mathrm{NaOH}$ buffer, $\mathrm{pH} 10.0$ for $72 \mathrm{~h}$ at room temperature and then packed on to a glass column $(30 \mathrm{X} 0.8 \mathrm{~cm})$ with a flow rate of $0.9 \mathrm{~mL} / \mathrm{min}$. Active fractions of ion exchange chromatography were loaded onto the column. Fractions of $2 \mathrm{~mL}$ were collected and the absorbance in each fraction was measured at 280 and $469 \mathrm{~nm}$ for the enzyme activity. The molecular weight was determined using $10 \%$ sodium dodecyl sulfate - polyacryl-amide gel electrophoresis (SDSPAGE).

\section{Determination of protein concentration}

The concentration of protein was determined by Lowry's Method[14].

\section{Laccase enzyme inhibitor Studies}

The effects of Sodium azide and EDTA on purified enzyme activity were tested using ABTS as substrate after pre-incubating the enzyme for $10 \mathrm{mins}$ at $25^{\circ} \mathrm{C}$ with inhibitors before addition of substrate[21].

\section{SDS-PAGE}

Molecular weight of the purified enzyme was determined under the reducing condition of the SDS-PAGE according to Laemmli method[12].

\section{DNA extraction and ITS amplification}

Mycelia were grown on potato dextrose agar, harvested using a scalpel, transferred into Epperdorf tubes, small amount of autoclaved refined sand (Sigma) was added and ground to fine paste with pestle-like stick (High Media), $400 \mu 1$ of DNA Extraction buffer $\mathrm{pH} 8(1 \mathrm{M}$ Tris- $\mathrm{Cl} \mathrm{pH} 8.0$; $1 \mathrm{M} \mathrm{NaCl} ; 200 \mathrm{mM}$ EDTA pH $8.0 ; 10 \% \mathrm{SDS} ; 0.1 \% \beta$ - Mercaptoethanol) was added and centrifuged at $4^{\circ} \mathrm{C}(12000 \mathrm{~g})$ for 10 mins. To the collected supernatant $300 \mu 1$ Phenol and 300 $\mu 1$ Chloroform: Isoamylalcohol (24:1) were added and mixed gently. This was centrifuged $\left(12000 \mathrm{~g}, 4^{\circ} \mathrm{C}\right.$ for $\left.10 \mathrm{mins}\right)$, and aqueous phase was collected and $500 \mu 1$ chilled Isopropanol was added and incubated at $-20^{\circ} \mathrm{C}$ overnight. After the incubation, it was centrifuged $\left(12000 \mathrm{~g}, 4^{\circ} \mathrm{C}\right.$ for $\left.10 \mathrm{mins}\right)$, and the pellet was washed with chilled $70 \%$ ethanol centrifuged for $5 \mathrm{mins}$. The dried pellet was resuspended in $50 \mu 1$ of Tris EDTA (10Mm Tris and 1mM EDTA, pH 8.0) buffer.

Amplification of the ITS region of the rRNA gene was carried out with a modified method of Gerdes and Bruns[7], using primers ITS1-F and ITS4-B. The final concentration of $25 \mu \mathrm{l}$ PCR reaction volume were; $200 \mu \mathrm{M}$ each of dATP, dCTP, dGTP and dTTP, $2.5 \mathrm{mM} \mathrm{MgCl} 2,10 \mathrm{X}$ Taq.DNA Polymerase and 20Pico mole of each of the two primers (Banglore Genei). The PCR profiles were initial denaturation step of $94^{\circ} \mathrm{C}$ for $85 \mathrm{~s}$ followed by 25 amplification cycles of 
denaturation, annealing and extension. The temperature and times for these steps were $95^{\circ} \mathrm{C}$ for $35 \mathrm{~s}, 55^{\circ} \mathrm{C}$ and $55 \mathrm{~s}$ and $72^{\circ} \mathrm{C}$ for 2 mins with further incubation at $72^{\circ} \mathrm{C}$ for $10 \mathrm{mins}$. The amplified PCR products were resolved on a $1.2 \%$ agarose gel, and stained with Ethidium bromide. A $1 \mathrm{~kb}$ ladder DNA marker (GeneRuler ${ }^{\mathrm{TM}}$ ) was used as a size standard.

\section{Sequencing and Phylogenetic Analysis}

The PCR products were purified using Exonuclease I and Shrimp Alkaline phosphatasa in buffer (EXOSAP Kits). Both strands of the amplified region were sequenced using fluorescent dye terminator chemistry and were run on $\mathrm{ABI}$ 3130 (4 capillary) or 3730XI (96 capillary) Automated Sequencer (Perkin Elmer Applied Biosystems, Foster City, CA), following the manufacturer's protocols. Sequencing primers were ITS1-F, 5.8S, 5.8SR and ITS4-B. Oligonucleotide sequences for primers $5.8 \mathrm{~S}$ and $5.8 \mathrm{SR}$ were given in Vilgaly and Hester[23]. Sequence contigs were assembled and edited using Sequencer 3.0 software (Gene codes Corporation, Ann Arbor, MI).

Phylogenetic trees were constructed by using all cloned sequences together with all non redundant large subunit (nLSU) sequences of named Pleurotus species obtained from GenBank. The multiple alignments of all the sequences were performed using CLUSTAL W (http://www.ebi.ac.uk/Tools $/ \mathrm{msa} /$ clustalw2/), followed by manual adjustments. The phylogenetic analyses was carried out using sequence data of ITS 5.8s and 28s ribosomal RNA gene from LAU 09 (wild) of P. pulmonarius and corresponding GenBank data of related species. The identical sequences were merged into one input sequence when running the computer programs to generate the phylogenetic trees constructed by UPGMA, Neighbor-joining (NJ) and parsimony methods. The boostrap test for estimating the reliability of phylogenetic tree topology was performed using 100 replications by the SEQBOOT program[5]. The consensus tree was obtained by running the consense program[5].

\section{Results and Discussion}

The laccase enzyme activity of the wild and mutant strains of P. pulmonarius was shown (Figure 1), with highest yield (2.5 Uml-1) obtained by LAU 90 (mutant) comparing with (1.75 Uml-1) obtained by LAU 90 (wild). The results obtained by the LAU 90 strain have shown an improved enzymes production over wild type (LAU 09).

Th The highest production of laccase, enzyme could be as result of efficient lignin-degrading ability of $P$. pulmonarius. Basidiomycetes fungi are the most efficient lignin-degrading organisms that produce mainly laccases, manganese peroxidase, and lignin peroxidase[9]. These enzymes present a non-specific biocatalyst mechanism and have been used for bioremediation process due to their ability to degrade azo, heterocyclic, reactive and polymeric dyes[1,6]. The increased yield in laccase production by LAU 90 is an evidence of true strain improvement. This correlate with work of Kang et al[10], who reported an improving enzyme pro- duction in Aspergillus niger through UV-light mutation, Rhizopus oryzea[22], mycelia cell and sporophore production in P. florida and P. sajor-caju[20].

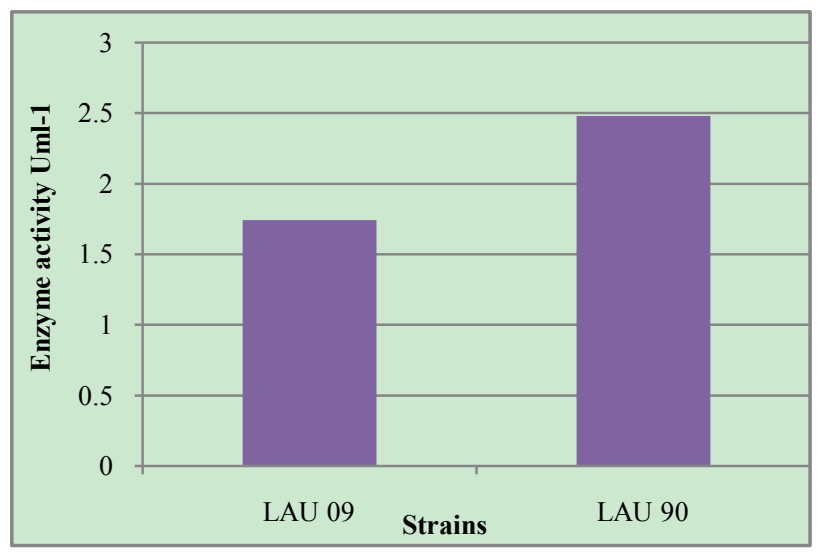

Figure 1. Laccase activity of wild and mutant strains of Pleurotus pulmonarius

The production of laccase enzyme was significantly increased in mutant (LAU 90) and of P. pulmonarius in comparison to their wild type (LAU 09) (Figure 2). All the evaluated temperature ranges $\left(25^{\circ} \mathrm{C}-50^{\circ} \mathrm{C}\right)$ supported the laccase production satisfactorily, with highest yield at $30^{\circ} \mathrm{C}$ for both mutant and hybrid strains. The optimum temperature obtained for laccase production by mutant and hybrid strains of $P$. pulmonarius is $30^{\circ} \mathrm{C}$ whereas Okamoto et al[17] reported $50^{\circ} \mathrm{C}$ as active optimum temperature for laccase production from $P$. ostreatus. Gomes et al[9] reported the optimum temperature for laccase production by the following organisms; Lentinus strigellus $\left(55-60^{\circ} \mathrm{C}\right)$, Picnoporus sanguineus $\left(60-70^{\circ} \mathrm{C}\right)$, Phenllinus rimosus $\left(60^{\circ} \mathrm{C}\right)$.

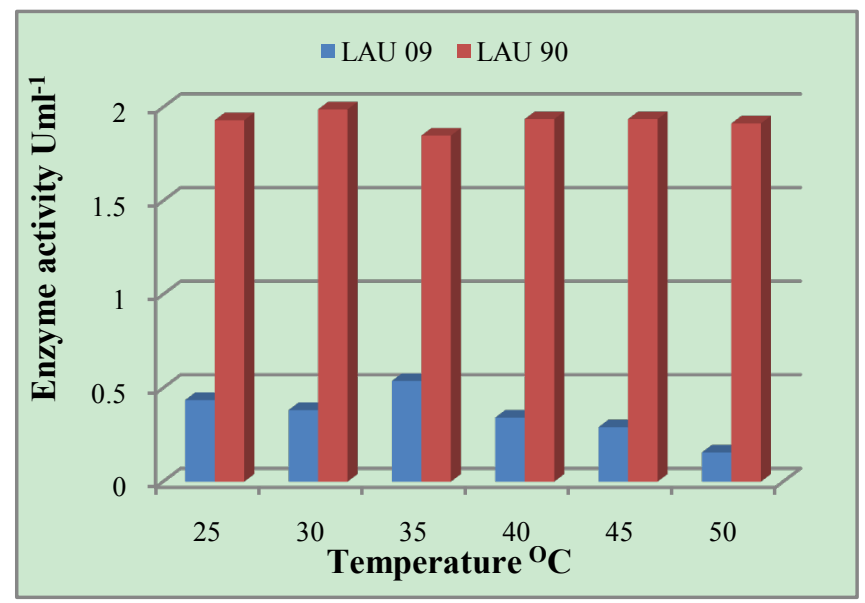

Figure 2. Effect of temperature on laccase activity of wild and mutant strains of $P$. pulmonarius

The optimum $\mathrm{pH}$ for laccase enzyme for mutant strain of $P$. pulmonarius is $\mathrm{pH} 5$, due to highest yield of laccase enzyme obtained at $\mathrm{pH} 5$ for mutant strain (Figure 3). The sharp decreases in the yield of laccase were observed in both wild and mutant strains above $\mathrm{pH} 5$. In the present study $\mathrm{pH} 5$ was obtained as optimum $\mathrm{pH}$ for laccase production while Okamoto et al[17] reported $\mathrm{pH} 6$ as optimum $\mathrm{pH}$ value for laccase production by $P$. ostreaus. 


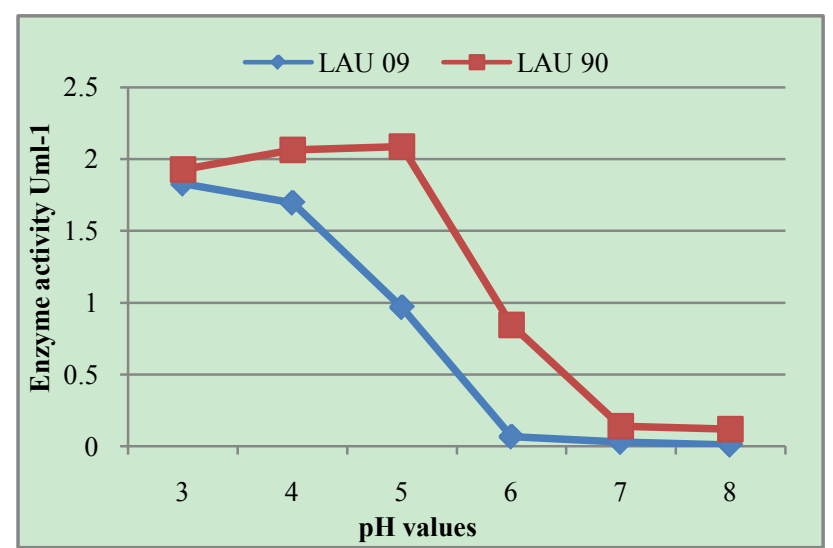

Figure 3. Effect of $\mathrm{pH}$ on laccase activity of wild and mutant strains of $P$. pulmonarius

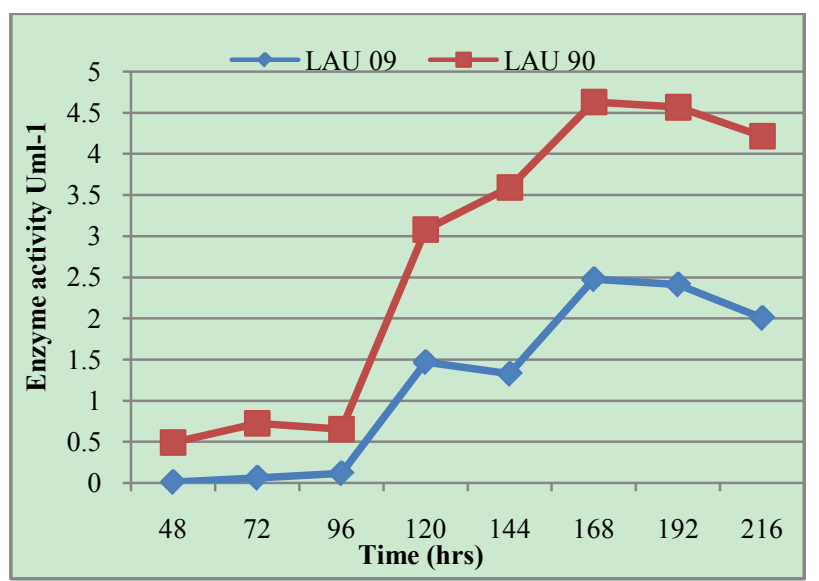

Figure 4. Effect of incubation period on laccase activity of wild and mutant strains of $P$. pulmonarius

The mutant (LAU 90) strain of P. pulmonarius has shown an improved yield of laccase enzyme production over the wild types (LAU 09) (Figure 4).

The optimum incubation period for laccase by LAU 90 and LAU 09 were obtained at $144 \mathrm{hrs}$ and $168 \mathrm{hrs}$ respective, while the laccase yield reduced below or after these incubation periods. The optimal condition for laccase production might be as a result of exponential growth of the organisms which has previously determined[26].

The purification fold, total enzyme activity, protein concentration and specific enzyme activity of purified laccase were shown Table 1 . The acetone precipitation at single fold of enzyme purification, with highest total enzyme activity ( $1640 \times 10^{-4} \mathrm{IU} / \mathrm{mg}$ ) obtained by LAU 90 , while the wild strain (LAU 09) produced $360 \times 10^{-4} \mathrm{IU} / \mathrm{mg}$. The result obtained in this study is higher than that of Kumar and Srikumar[11], which reported $2.8 \times 10^{-4} \mathrm{IU} / \mathrm{ml}$ and $5.6 \mathrm{X}$ $10^{-4} \mathrm{IU} / \mathrm{ml}$ for laccase enzyme activity and specific activity respectively from Opuntia vulgaris. The highest enzyme activity and specific activity obtained in this study may be as result of acquired potential by mutant (LAU 90) strain of $P$. pulmonarius for increased enzyme production. As the enzyme becomes more purified at step two and three purification methods (Ion exchange Sephadex A-50 and Gel filtration Sephadex G-100 chromatograph), the total enzyme activity decreased, while specific enzyme activity increased accordingly (Table 1). The specific enzyme activity obtained in LAU 90 (mutant) is higher than that of LAU 09 (wild type), which implied that the purified laccase of mutant strain might be more active than that of wild type strain. Kumar and Srikumar[11] reported a purified laccase at purification folds of 11.6 and 11.9 with yields of 18.6 and $15.5 \%$ respectively, using sephadex G-100 gel permeation chromatograph.

Table 1. Purification fold of laccase enzyme

\begin{tabular}{|c|c|c|c|c|}
\hline Steps & Total enzyme & $\begin{array}{c}\text { protein } \\
\text { conc }\end{array}$ & Specific activity & purification \\
\hline & activity & $(\mathrm{mg})$ & $(\mathrm{IU} / \mathrm{mg}) \times 10^{-4}$ & fold \\
\hline & $(\mathrm{mol} / \mathrm{min}) \times 10^{-4}$ & & & \\
\hline
\end{tabular}

Acetone
\begin{tabular}{|c|c|c|c|c|}
\hline Precipitation & & & & \\
\hline LAU 09 & 360.3 & 116.20 & 3.10 & 1 \\
\hline LAU 90 & 1640.0 & 230.0 & 7.13 & 1 \\
\hline Ion exchange Chromatograph (Sephadex A-50) \\
\hline LAU 09 & 209.3 & 5.6 & 37.38 & 17 \\
\hline LAU 90 & 352.0 & 8.4 & 41.9 & 5.0 \\
\hline Gel filtration Chromatograph (Sephadex G-100) \\
\hline LAU 09 (97KDa) & 50.6 & 0.6 & 84.33 & 7.5 \\
\hline LAU 90 (97KDa) & 71.7 & 0.8 & 89.63 & 8.0 \\
\hline
\end{tabular}

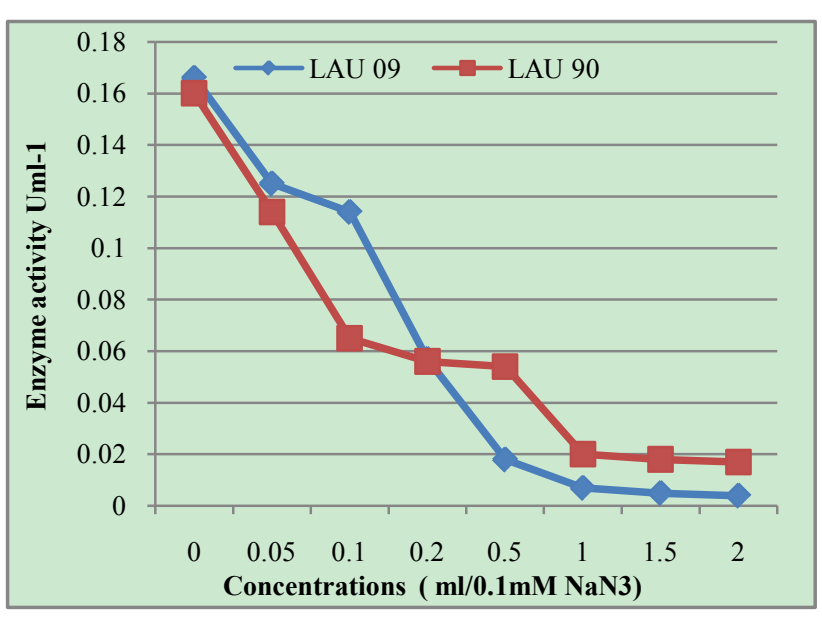

Figure 5. The lacccase enzyme inhibition test by Sodium azide

The activity of purified laccase from wild type (LAU 09) was highly inhibited by sodium aside, while mutant was lesser inhibited (Figure 5). The sharp inhibition was observed at $0.1 \mathrm{ml} / 0.1 \mathrm{mM} \mathrm{N}_{\mathrm{a}} \mathrm{N}_{3}$ in wild type, while mutant was inhibited sharply at $0.5 \mathrm{ml} / 0.1 \mathrm{mM} \mathrm{N} \mathrm{N}_{\mathrm{a}} \mathrm{N}_{3}$. The activity of purified laccase was inhibited by $100 \mathrm{mM}$ EDTA, using ABTS as substrate, the rate of enzyme inhibition increased as the concentration of EDTA is increased (Figure 6) in all the strains (both wild and mutant) laccase inhibition was observed at low concentration of $0.1 \mathrm{ml} / 100 \mathrm{mM}$ EDTA, and sharp increased in enzyme inhibition was obtained at $0.5 \mathrm{ml} / 100 \mathrm{mM}$ EDTA. The result obtained in present study agrees with Soden et al[21] and Pang et al[18] with reported EDTA and sodium azide as strong inhibitory agents for laccase enzyme. 


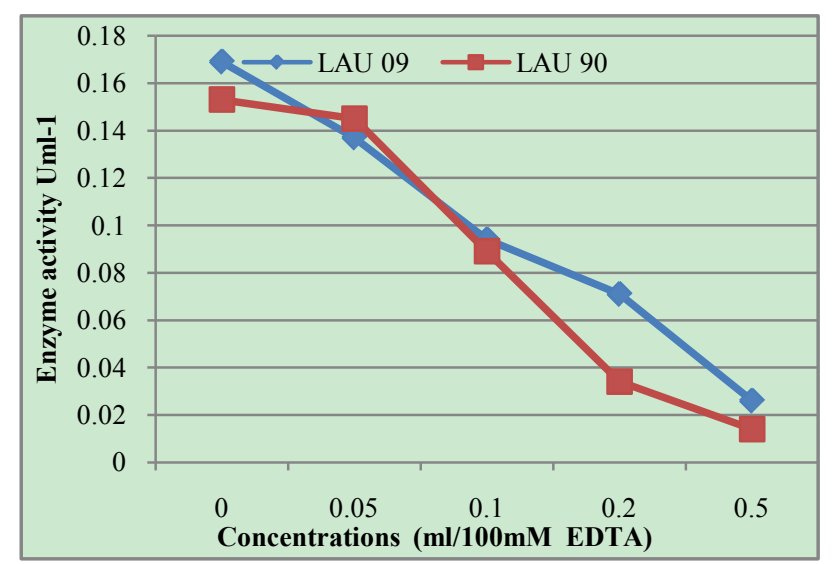

Figure 6. The lacccase enzyme inhibition test by EDTA

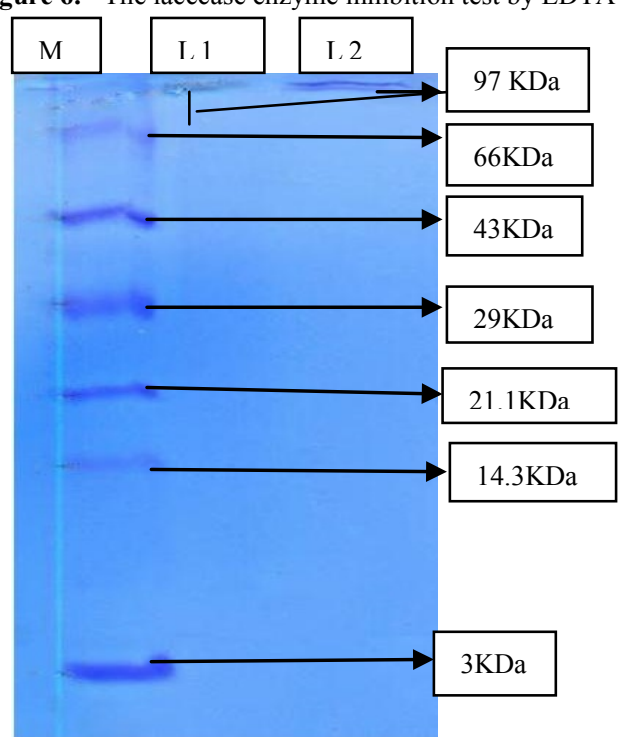

$\mathrm{LM}=$ protein molecular weight, $\mathrm{L} 1=\mathrm{LAU} 09, \mathrm{~L} 2=\mathrm{LAU} 90$

Figure 7. Protein (laccase) Molecular Weight as visible on $10 \%$ SDS-PAGE after staining with Coomassie Brilliant Blue

The molecular weight of the purified laccase was deter- mined in comparison with the molecular weight of the standard proteins such as Phosphorylase b (97.4KDa), Bovine serum albumin $(66 \mathrm{KDa})$, Ovalbumin $(43 \mathrm{KDa})$, Carbonic Anhydrase $(29 \mathrm{KDa})$, soybean trypsin inhibitor $(21.1 \mathrm{KDa})$, lysozyme $(14.3 \mathrm{KDa})$ and aprotinin $(6.5 \mathrm{KDa})$. The molecular weight of the proteins was calculated to be approximately 97KDa for LAU 09 and LAU 90 (Figure 7). Kumar and Srikumar[11] reported different bands (43KDa, $90 \mathrm{KDa}$ and $137 \mathrm{KDa}$ ) for laccase species under non-reducing SDS - PAGE, whereas a molecular weight of $72 \mathrm{KDa}$, $46 \mathrm{KDa}$ and $44 \mathrm{KDa}$ were previously reported by Pang et al[18] for different species of laccase enzymes. The same molecular weight of 97KDa obtained in both LAU 09 (wild) and LAU90 (mutant) suggested that the enzyme produced by both wild and mutant strains may not be differed.

The phylogenetic analyses using sequence data of ITS $5.8 \mathrm{~s}$ and $28 \mathrm{~s}$ ribosomal RNA gene from P. pulmonarius (LAU 09) and corresponding GenBank data of related species was shown in Figure 8. The outgroup arising from the root of the phylogenetic tree for the P. pulmonarius (accession number: JF736658) for phylogenetic evaluation is $P$. tuberregium (AY450344) from GenBank database. P. pulmonarius LAU 09 formed a phylogenetic cluster with $P$. pulmonarius complex at top of phylogenetic tree with bootstrap value of $77 \%$, which confirmed the close evolutionary lineage of the strain with $P$. pulmonarius complex from GenBank database. The cladistic position of the P. pulmonarius (LAU 09) strain in the phylogenetic trees suggested that there was common ancestor, sub ancestors diverged majorly at early stages of evolution[24]. The phylogenetic analyses based on the PCR-RFLP data of the partial 26srDNA has also reported[2] which revealed that 9 of the biological species, the $P$. cornucopiae complex, $P$. cystidiosus complex, $P$. salmoneos-tramineus, complex, $P$. dryinus, $P$. nebrodensis, $P$. smithii, and $P$. ulmarius were congruent with independent phylogenetic lineages.

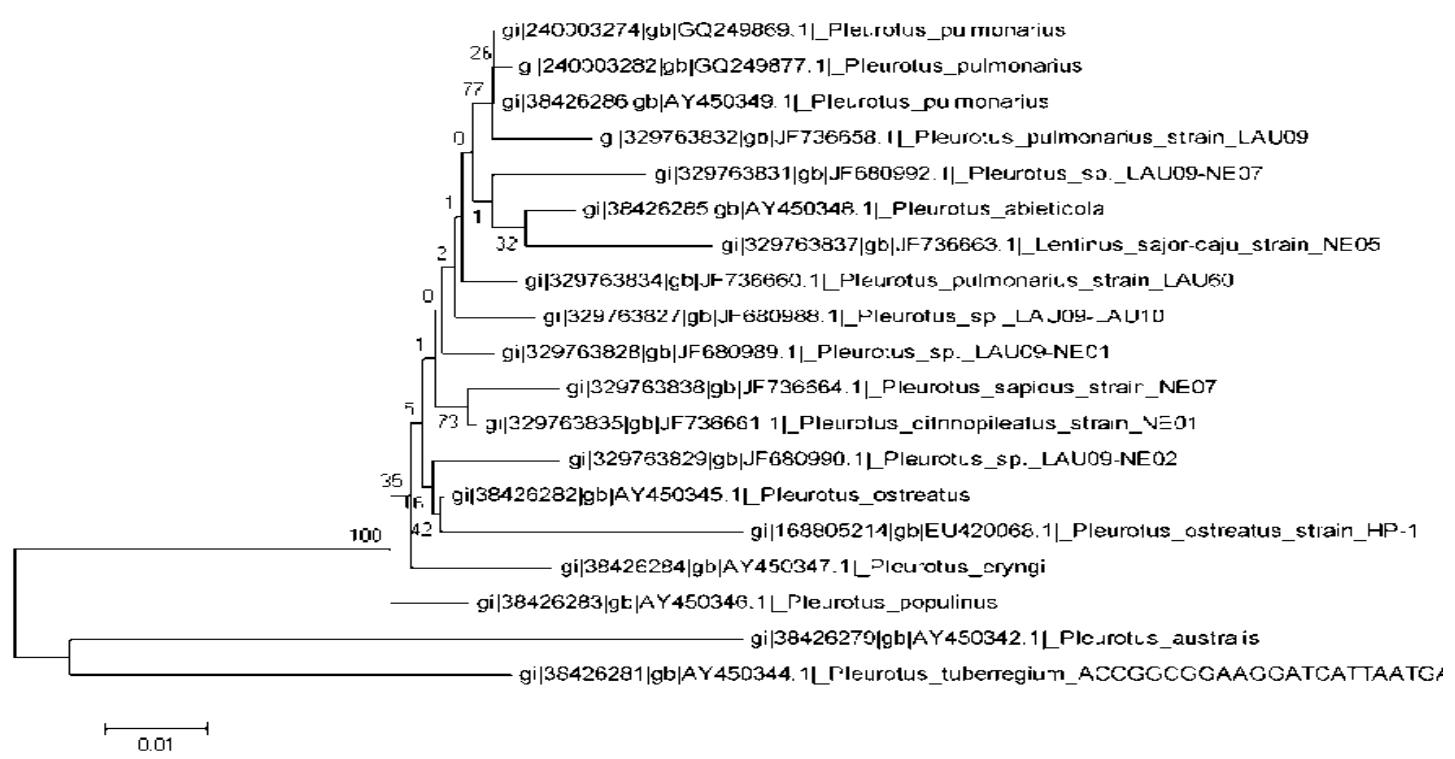

Figure 8. The Phylogenetic trees of LAU 09 (wild) constructed by UPGMA, with boostrap values from 100 replicates showing maximum similarity with LAU 09 (wild) and the homogeneous strains of Pleurotus species 
Table 2. The total length (1150) of nucleotides sequence of LAU 09 (wild)

GCGGAAGGATCATTAATGAATTCACTATGGAGTTGTTGCTG
GCCTCTAGGGGCATGTGCACGCTTCACTAGTCTTTCAACCAC
CTGTGAACTTTGATAGATCTGTGAAGTCGTCCTCAAGTCG
TCAGACTTGGTTGCTGGGATTTAAACTTCTCGTGTGACAA
CGCAGTCTATTTACTAACACACCCAAATGTATGTCTACGA
ATGTCATTTAATGGGCCTTGTGCCTATAAACCATAATACAAC
TTTCAACAACGGATCTCTTGGCTCTCGCATCGATGAAGAAC
GCAGCGAAATGCATAAGTAATGTGAATGCAGAATCAGT
GAATCATCGAATCTTTGAACGCACCTTGCGCCCCTTGGTATT
CCGAGGGGCATGCCTGTTTGAGTGTCATTAAATTCTCAAACT
CACATTTATTTGTGATGTTTGGATTGTTGGGGGTTGCTGGCT
GTAACAAGTCGGCTCCTCTTAAATGCATTAGCAGGACTTCTC
ATTGCCTCTGCGGATGATGTGATAATTATCACTCATCAATAG
CACGCATGAATAGAGTCCAGCTCTCTAATCGTCCGCCAGGC
GAATTTGACAATTGACCTCAAATCAGGTAGGACGTACGCG
GTGAATTAAGCATATCAATAAGGGGAGGAAAAGAAATA
ACAAGGATTCCCCTAGTAACTGCGAGTGAAGCGGGAAAAG
CTCAAATTTAAAATCTGGTGGTCTTTGGCCATCCGAGTTGTA
ATCTAGAGAAGTGTTATCCGCGCTGGACCGTGTACAAGTCC
CCTGGAATGGGGCGTCATAGAGGGTGAGAATCTCGTCTTTG
ACACCGACTACCAGGGCTTTGTGATGCACTCTCAAAGAGTC
GAGTTGTTTGGGAATGCAGCTCAAAATGGGTGGGAAATTCC
ATCTAAAGCTAAATATTGGCGAGAGACCGATAGCGAACAA
GCGCAGTGAGGGAAAGATGAAAAGAACTTTGGAAAGAGAG
TTAAACAGTACGTGAAATTGTTGAAAGGGAAACGCTTGAAG
TCAGTCGCGTCTGCCAGGGATCAACCTTACTTTTGTGGGGCG
TACTTCCTGGTTGATGGGTCAGCATCAGTTTTGGTCGCTGGA
TAAAGGTCAGAGAAATGTGGCACCTTCGGGTGTG

The edited nucleotide sequence of LAU 90 (mutant) show no similarity with any available data at GenBank database after blasting at national centre for Biotechnology information (NCBI) website. The nucleotide sequence of LAU 09 (wild) and LAU 90 (mutant) were shown in Table 2 and 3 with total number of sequence nucleotides very high (1150) in LAU 09 (wild) compare to 750 obtained in LAU 90 (mutant). Beside the shorter length of nucleotides sequence in the mutant strain, the arrangement of the nucleotides sequence in the mutant strain has widely altered.

Table 3. The total length (750) of nucleotides sequence of LAU 90 (mutant)

AGCCAACCCGAGGGAGTAAAAGGATTTTTTTCTAAGTTGTT
GCTGGCCCCCTCCCGTAGAGCACGCGGGTACTAGTTTTCTC
ATATCCGCTATGCACTGAACTAGGGTTGATTACAACAGGT
CTTTATAGACTTGGGAAATCTGTCCTATGCTTTTATGGGAC
TTCACTTTTATAATGTCTTCCTCATACAACGCATTTATTTCA
ACTTTCATCTACGGATCTGTTGGCTCCGCATCAAAAAACAA
CTCCCCACTTGCAACAGAACTGTGAATTGGCTAATTCAAG
GAACCAGCCGCTCTATGAAAAGAGATATCGCCCTTTGGAA
TTCAGTAAGGCATGCCAATTTGACAGCCAGCCCCCTCGGA
TAGGCATAAGCAGTGCGGTGTGTGAGTTGTTGAATTTGCTC
ATTCTCAAATTTATTTGATATGTGTTAATTGCATCCCCTTCC
TCGATGTGACCAAGAGCACCGAATTTTAAATTTAGGTTTTT
CCGCCTTCCCGTAAGTAAGGAGGGGATCCCTGGTTAGTTTC
TTTCCCCCCCTCATTAATAGGCTTAATTTCACGGGGTATC
CCTACCTGATTGAGGGCAGAATGGTCAAATTGGCCCGGCG
GAGGATTAACCCAGCTGGATTTTGTTCTACCGCGCTACTAA
CGAGTGAAAATTTTATCACAATGCGCAGTGGCAATGATAA
CTCTGGCAATTGCTTTAAGAAGAACTGGAGACGTTAC-
CATCACCTGCCACCACCACTCCCTAC

The result obtained in this study has shown the improved performance in laccase production by the mutant (LAU 90) strain over the wild (LAU 09) strain. So also, the molecular variation with evolutionary divergence of the mutant strain from the wild type is true evidence of a novel strain of $P$. pulmonarius.

\section{ACKNOWLEDGMENTS}

The Director of NEIST, India is gratefully acknowledged for granting facilities available to carry out this research, so also TWAS, Italy; and CSIR for the award of Postgraduate Fellowship given to me (Adebayo, E.A) and utilized at NEIST, CSIR, Jorhat, India, and also to the authority of LAUTECH, Ogbomoso, Nigeria for granting the study leave to utilize the award.

\section{REFERENCES}

[1] Baldrian, P., and Snajdr, J., 2006, Production of ligninolytic enzymes by litter-decomposing fungi and their ability to decolorize synthetic dyes. Enzyme Microbiol. Technol 39: 1023-1029

[2] Bao, D., Ishihara, H., Mori, N., Kitamoto, Y., 2004, Phylogenetic analysis of oyster mushrooms (pleurotus spp.) based on restriction fragment length polymorphisms of the 5' portion of 26s rDNA. J wood sci, 50: 169-176

[3] Bajpai, P., 1999, Application of enzymes in the pulp and paper industry. Biotechnol Prog 15:147-57

[4] Claus, H., Faber, G., König, H., 2002, Redox-mediated decolorization of synthetic dyes by fungal laccasse. Appl Microbiol Biotechnol 59:672-678

[5] Felsenstein, J., 1989, PHYLIP -Phylogeny Inference package (version 3.2). Cladistic 5:164-166

[6] Forgacs, E., Cserháti, T., Oros, G., 2004, Removal of synthetic dyes from wastewaters: a review. Environ. Intern, 30, 953-971

[7] Gerdes, M., and Bruns, T. D., 1993, ITS primers with enhanced specificity for basidiomycetes- application to the identification of mycorrhizea and rusts. Molecular Ecology 2: 113-118

[8] Gianfreda, L., Xu, F., Bollag, J. M., 1999, Laccases: A useful group of oxidoreductive enzymes. Biorem. J. 3:1-25

[9] Gomes, E., Aguiar, A. P., Carvlho, C. C., Bonta, R. M., Desilva, R., Boscolo, M., 2009, Ligninases production by Basidiomycetes strains on lignocellulosic Agricultural residues and their application in the decolorization of synthetic dyes. Brazillian journal of Microbiology 40:31-39

[10] Kang, S .W., Ko, E. H., Lee, J. S., Kim, S.W., 1999, Overproduction of beta-glucosidase by Aspergillus niger mutant from lignocellulosic biomass. Biotechnol. Lett 21: 647- 650

[11] Kumar, G.N., and Srikumar, K., 2010, Thermophilic Laccase from xerophytes species Opuntia vulgaris. Research article (Wileyonlinelibrary.com) DOI 10.1002/bmc.1506

[12] Laemmli, U. K., 1970, Cleavage of structural proteins during assembly of head of bacteriophage T4. Nature 227: 680-685

[13] Leonowicz, A., Cho, N.S, Luterek, J., Wilkolazka, A., Wojtas-Wasilewska, M., Hofrichter, M., 2001

[14] Fungal laccase: properties and activity on lignin. J Basic Microbiol, 41:185-227 
[15] Lowry, O.H., Rosebrough, N.J., Farr, A.L., Randall, R.J., 1951, Protein measurement with the folin phenol reagent. J. Bio. Chem 193.265-275

[16] Machado, K. M. G., and Matheus, D. R., 2006, Biodegradation of remazol brilhant blue $\mathrm{R}$ by ligninolytic enzymatic complex produced by Pleurotus ostreatus. Braz. J. Microbiol, 37: $468-473$

[17] NYANHONGO, G. S., GOMES, J., GÜBITZ, G., ZVAUYA, R., READ, J. S., STEINER, W., 2002, Production of laccase by a newly isolated strain of Trametes modesta. Biores. Technol 84, 259-263

[18] Okamoto, K., Yanagi, S. O., Sakai, T., 2000, Purification and characterization of extracellular laccase from Pleurotus ostreatus. Mycoscience, 41: 7-13

[19] Pang, Q., Zhang, S., Shi, X., Shu, F., Wu, D., 2005, Purification and characterization of phenoloxidase from amphioxus Branchiostoma belcheri. Tsingtauense, 19: 139-148

[20] Riva, S., 2006, Laccases: blue enzymes for green chemistry. Trends Biotechnol 24:219-226

[21] Sandhya, R., Meera, P., Tewari, R.P., Krishna, V., 2006, Development of sporeless/low sporing strains of Pleurotus through mutation. World Journal of Microbiology \& Biotechnology 22: 1021- 1025
[22] Soden, D. M., Callaghan, J. O., Dobson, A. D. W., 2002, Molecular cloning of a laccase isozyme gene from Pleurotus sajor-caju and expression in the heterologous pichia pastoris host. Microbiology 148: 4003-4014

[23] Suntornsuk, W., Hang, Y. D., 2008, Strain improvement of Rhizopus oryzae for production of (+)- lactic acid and glucoamylase. Lett. Appl. Micobiol 19: 249-252

[24] Vilgalys, R., and Hester, M., 1990, Rapid genetic identification and mapping of enzymatically amplified ribosomal DNA from several Cryptococcus species. J. Bacteriol 172, $4238-4246$

[25] Vilgalys, R., Moncalvo, J. M., Liou, S.R.,Volovcek, M., Recent advances in molecular systematics of the genus Pleurotus. In Mushroom Biology and Mushroom Products, pp. 91-102. Edited by D. J. Royse. PennState: PennState University, 1996

[26] Yaropolov, A. I., Skorobogat'ko, O. V., Vartanov, S. S., Varfolomeyev, S. D., 1994, Laccase: Properties, Catalytic Mechanism, and Applicability. Appl. Biochem. Biotechnol 49:257-280

[27] Zervakis, G., Philippoussis, A., Ioannidou, S., Diamantopoulou, P., 2001, Mycelium growth kinetics and optimal temperature conditions for the cultivation of edible $\mathrm{Mu}-$ shroom species on Lignocellulosic substrates. Folia Microbiol, 46: 3: 231- 234 